\title{
Malaysia and the Factors that Influence Its Seed Industry: Natural Resources, Policies, Market and Fundings
}

\author{
Chua Kim Aik ${ }^{1}$, German Mingramm ${ }^{1}$ and Fakhrul Anwar Zainol ${ }^{2}$ \\ 1. Green World Genetics Sdn Bhd., 40, Jalan KIP 10, Taman Perindustrial KIP, Kepong 52200, Kuala Lumpur, Malaysia \\ 2. Faculty of Economics and Management Science, University of Zainal Abidin, Kuala Terengganu 21300, Malaysia
}

\begin{abstract}
Malaysia, situated in Southeast Asia, is a relatively small country of 33 million hectares of land, and with a total cultivable area estimated in 14.2 million ha. However, in 2013, only 53\% of it was cultivated. Remarkably enough, in 2012, 67\% of the whole land used under agriculture was destined for oil palm plantations. Likewise, Malaysia has been recognized as one of the twelve mega-diversity countries of the world, thanks to its rich variety of species and diverse number of ecosystems. Furthermore, as Malaysia lies in the equatorial zone, the average temperature throughout the entire year is $26^{\circ} \mathrm{C}$; which is controlled by the northeast and southwest monsoons, and consequently, receiving around 2,000 $\mathrm{mm}$ to 2,500 $\mathrm{mm}$ of rainfall annually. In addition, Malaysia has an annual average of 990 billion $\mathrm{m}^{3}$ of water resources inside the entire territory. Moreover, as Malaysia realized the importance of shifting into a knowledge-based economy, it's now really focused on the development of human and intellectual capital in order to produce adequate supply. In that way, under the Malaysia Education Blueprint from 2013 to 2015, a sum of RM 41.3 billion is expected to be allocated in 2016, to improve the quality of education. Conjointly, the agriculture in Malaysia is a fundamental piece in the country's economy, contributing to the National Gross Domestic Product (GDP), as in 2013 this sector employed more than 1.6 million people. On the other hand, in Malaysia two distinct Agricultural Policies have been established to give strategic direction to the agricultural sector: The Policy before Independence (1948-1957) and The Policy after the independence (1957-2020) (which is as well, formed by several policies). In conjunction, as Malaysia aspires to become a developed country, it nourishes its research culture; being the public sector an important contributor for the agricultural research funding. Notwithstanding, a substantial factor that has contributed in the development of the seed industry in Malaysia, is the fact of having the "Legislation" in place; with the establishment of the Protection of New Plant Varieties (PNPV) Act, which came into force in October of 2008. To finalize, Malaysia is now certainly facing limitations towards the development of the seed industry, which are: lack of new local varieties, lack of mandatory seed quality control system, unorganized information of the seed industry, inadequate number of trained personnel in the seed industry, lack of private sector involvement.
\end{abstract}

Key words: Malaysia, Malaysia Seed Industry, natural resources, policies, funding, human capital.

\section{Malaysia and Its Natural Resources}

Malaysia, situated in Southeast Asia, is a relatively small country of 33 million hectares of land, and with a population of 30.33 million people [1]. It is formed by two regions: (1) the Peninsular Malaysia in the west, which lays between Thailand and Singapore; (2) and the states of Sabah and Sarawak that are located in the east, inside the island of Borneo, where Brunei and part of Indonesia are also positioned. The Peninsular Malaysia is separated from the states of Sabah and

Corresponding author: Fakhrul Anwar Zainol, associate prof., research fields: business strategies, human capital development and strategic management.
Sarawak by the South China Sea.

Moreover, Malaysia is considered a federal constitutional monarchy that is divided into 13 different states and one federal territory (Wilayah Persekutuan), including the cities of: Kuala Lumpur (legislative capital), Labuan and Putrajaya (administrative capital). In the Peninsular Malaysia, a mountainous range known as Banjaran Titiwangsa, divides the east of the peninsula from the west; and approximately $61 \%$ of the peninsula is less than $100 \mathrm{~m}$ above the sea level, making its land suitable for cultivation. On the other hand, the interior of Sabah is intersected by a series of mountain chains; in which 
the most outstanding of all, is the Crocker range, with its highest point at Gunung Kinabalu (4,101 m). Likewise, Sarawak is mostly mountainous as well, and its uppermost range is what forms the border with Indonesia [2-4].

Furthermore, the total cultivable area estimated in Malaysia is 14.2 million ha, which corresponds to the $43 \%$ of the entire territory; while two thirds of the whole land surface is forested. Nevertheless, in 2013, only 7.554 million ha of the total cultivable area were cultivated (approximately 53\% of it) [1]; and according to Su Mei Toh [5], in 2012, 67\% of the whole land used under agriculture (5.076 million ha), was destined for oil palm plantations; which were mostly placed in the best regions of arable land.

Interestingly enough, Malaysia has been recognized as one of the twelve mega-diversity countries of the world, thanks to its rich variety of species and diverse number of ecosystems. There are over 15,000 species of known flowering plants; 2,650 species of trees; around 1,500 terrestrial vertebrates; 280 species of mammals; 624 species of birds; 158 species of amphibians and reptiles; approximately, 150,000 invertebrates; 150 species of coral; at least, 1,161 species of fish; 700 species of fungi; and 832 species of mosses, all of them which are found throughout the entire country [6]. In addition, Malaysia houses almost 2,000 different species of orchids; and various species of wild and semi-wild forest food and fruit-bearing plants. However, even though the total number of plants and land vertebrate species is not the highest in South East Asia, it is for the number of species per $\mathrm{km}^{2}$ [3].

Correspondingly, as Malaysia lies entirely in the equatorial zone, the climate has a fairly uniform average temperature of $26^{\circ} \mathrm{C}$ throughout the entire year; ranging from $32{ }^{\circ} \mathrm{C}$ during the day to $22{ }^{\circ} \mathrm{C}$ during the night in the lowlands; and between $32{ }^{\circ} \mathrm{C}$ to $15^{\circ} \mathrm{C}$ in the highlands [3]. Likewise, as the climate is controlled by the northeast and southwest monsoons, it is common to have rains during the whole year, averaging $2,000 \mathrm{~mm}$ to $2,500 \mathrm{~mm}$ annually. The northeast monsoon occurs from October to March, producing heavy rains in the east coast of the Peninsular Malaysia; and consequently, causing recurrent and extensive inundations. In fact, this monsoon is the responsible one of the wettest season in Sabah and Sarawak. Alternatively, the southwest monsoon happens between May and September, and is a drier period for the entire country. Nonetheless, April, which is the interval month between these two monsoons, is characterized by heavy rainfalls [1].

In terms of the water resources, Malaysia has an annual average of 990 billion $\mathrm{m}^{3}$ on the entire country. However, 360 billion $\mathrm{m}^{3}$ of them (36\%), return to the atmosphere as evapotranspiration; 566 billion $\mathrm{m}^{3}$ of them (57\%) appear as surface runoff; and the remaining 64 billion $\mathrm{m}^{3}$ of them (7\%) go to the recharge of groundwater. In addition, of the total 566 billon $\mathrm{m}^{3}$ of surface runoff, 147 billion $\mathrm{m}^{3}$ are found in Peninsular Malaysia; 113 billon $\mathrm{m}^{3}$ in Sabah; and 306 billon $\mathrm{m}^{3}$ are found in Sarawak. Conjointly, the Peninsular Malaysia is drained by a dense network of rivers and streams (there are about 150 major river basins); being the Pahang River, the longest one; as it follows a course of $434 \mathrm{~km}$ before reaching the South China Sea, and flowing off a drainage area of 29,000 $\mathrm{km}^{2}$. Additionally, there are other major rivers that feed into the South China Sea as well, which are: the Kelantan, the Terengganu, the Dungun, the Endau, and the Sedili rivers. Nevertheless, major river basins in the east of Malaysia, tend to be larger than those in the Peninsular Malaysia; in fact, the longest river in Malaysia is the Rajang (534 km) which is located in Sarawak [7].

\section{Malaysia and the Human Capital}

As Malaysia has realized the importance of shifting into a knowledge-based economy, it has understood that its main responsibility should lie con the development of human and intellectual capital in order to produce adequate supply, as well as to support and 
sustain, a flexible, agile, and mobile workforce with pertinent knowledge and skills. In that way, we could say that the most significant variables of the human capital, are with no doubt, the education and training; which can be measured of several forms, including: the cost on education and training, years of schooling, number of people in the enrollment, and level of education of the labor force.

Moreover, the government expenses on education and training, as a representation of a human capital variable, is meaningfully related to the economic growth parameter, which is represented by the Growth Domestic Product (GDP) [8]. Thereby, under the Malaysia Education Blueprint from 2013 to 2015, a sum of RM 41.3 billion is expected to be allocated in 2016, to improve the quality of education; and RM 2.446 billion to strength the higher education (RM 1.65 billion through the Public Service Department; RM 288 million through the Ministry of Education; RM 250 million through the Ministry of Higher Education; and RM 258 million through the Ministry of Health). Consistently enough, in efforts to improve the employees' income, by 2020, the government has to address $60 \%$ of 1.5 million new jobs, for workers with Technical and Vocational Education Training (TVET). So far, a sum of RM 4.8 billion has been allocated to 545 TVET institutions [9].

Complementarily, in order to improve the employability of the workforce, the following programs will be implemented during the next years.

First: 30\% of the Human Resources Development Fund (HRDF) will be allocated to appoint training programs to meet the needs of local industries in Sabah and Sarawak, as well as an Outplacement Centre to retrain retrenched workers.

Second: Train an additional 15,000 participants under the 1Malaysia Training Schemes (SL1M) with a RM 250 million share that will be entirely financed by Government Linked Companies (GLCs).

In the same manner, in order to enhance the management of foreign workers, a sum of RM 77 million will be provided by the Pembangunan Sumber Manusia Berhad (PSMB) to implement programs such as, training and replacement in selected fields like: hospitality, shipping, and transport. Notwithstanding, the Malaysian government keeps committed, that at least $30 \%$ of the decision making positions in the public and private sectors, should be filled by women. Including at the board of directors level. In addition, the government will continue monitoring the achievement of this policy [9].

\section{Malaysia's Agriculture and Its Policies}

Since many years ago, the agriculture in Malaysia has been a fundamental piece in the country's economy, by producing cultivated products for domestic consumption, as well as for using it as a source for foreign exchange. Besides, the agriculture in Malaysia also contributes to the National Gross Domestic Product (GDP), as it provides a considerable amount of employment, especially in the rural areas. In 2013, this sector employed more than 1.6 million people or $10.9 \%$ of the total country's employment, contributing more than $23 \%$ of the total export earnings, and adding $7.2 \%$ approximately, to Malaysia's GDP.

Nonetheless, the share of the agricultural sector in Malaysia's economy is declining every year. For instance, its share in GDP has declined from $29.9 \%$ in 1970 to $22.9 \%$ in 1980 ; decreasing up to $18.7 \%$ in 1990; and successively, diminishing up to $8.4 \%$ in 2000. In fact, despite of an increase in the absolute value, the share of the agricultural sector is still declining. However, the contribution of agriculture has increased from RM 51.3 billion in 2010 to RM 56 billion in 2013; while simultaneously, the share of agriculture has being reduced from $7.58 \%$ in 2010 to 7\% in 2014. Furthermore, the difficulties that have been faced by agriculture are mostly attributed to three factors.

(1) Shortage in Labor. This factor resulted from the increase of unproductive agricultural land, making the 
local farmers leave their fields; and as there are no local people attending the lands, the agricultural sector is now dependent of on foreign labor. More than 750,000 registered foreign labors were employed in 2012.

(2) Increase of Production Cost. This factor is caused by the increase of wages, by the price of agricultural inputs and by the capital cost.

(3) Low Productivity and Quality of Agricultural Produce. In order to obtain successful results from the fields, the agricultural sector needs to be constantly trained with sustainable transformation programs, which are formulated inside the National Agricultural Policies [10].

The National Agricultural Policies are official documents that are developed by the government, and serve as a guide for strategic direction in the agricultural sector in Malaysia. For most of the cases, an Agricultural Policy is formulated for a certain period of time, and once it expires, a new one gets created. In Malaysia, two distinct Agricultural Policies have been created during two different terms of history:

(1) The Policy before Independence (1948-1957). This Policy was established under the British colony interest, and was focused on primary commodities, such as: rubber, oil palm, cocoa and spices. During this period, the British government planted rubber fields for the production of raw materials that were used by the industrial and the manufacturing sectors in the United Kingdom, and in United States of America. Nonetheless, as they needed more people to work in the rubber plantations, immigrants from India were imported to work there. This circumstance certainly helped Malaysia to emerge as the world's top rubber producer; and to turn this crop into a significant contributor for the country's economy through the export income. Nevertheless, other food commodities, such as: rice, fruits, and vegetables, were only produced by small holders, including traditional farmers.
In that sense, the contribution of the agricultural sector was clearly significant; it provided employment and invited foreign investments in the form of plantation ownerships, such as: Dunlop, Guthrie and Harrison. Likewise, as the colonials built adequate infrastructures, such as: a road system, rail tracks, and a harbor, then it became easier to transport the commodities inside the country, and successively, outside the country. However, there was as well, another unfortunate reality running in Malaysia's agriculture; this alternate reality was dominated by the indigenous population that only produced for subsistence, and for self-consumption. The existence of these two distinct realities, occurred because the British Agricultural Policy neglected to provide opportunities, and to allow the participation of the Malays in the rubber plantations; so even though small holders showed interest on contributing, their ideas were promptly discouraged by the British. Situation that headed Malaysia's agriculture into two dissimilar directions. On one side, the rich and profitable rubber plantation that were owned by foreign capitalists; and on the other side, the hand-to-mouth subsistence paddy farming that was dominated by Malay peasants. Over time, this British Agricultural Policy affected the racial identification by type of employment. For instance, the paddy production was worked by Malays; the rubber fields were grown by Indians; and the vegetable terrains were farmed by Chinese. Curiously enough, this dichotomy became structural and institutionalized in Malaysia until present [11].

(2) The Policy after the independence (1957-2020). After the independence, Malaysia formulated four different Agricultural Policies, which are:

- The Malaya Economic Plan (1957-1983).

Once the independence was achieved, the Malaysian government continued with the colonial's Pre-independence Agricultural Policy; and setting up the agriculture's direction under the Government Economic Development Plan. The policies on 
Agricultural Development were published in: the First Malaya Plan (1956-1960); the Second Malaya Plan (1961-1965); and the First Malaysia Plan (1966-1970).

Furthermore, in addition of being influenced by the colonial's policy, which was focused on industrial crops for export markets; large vocationally forest surfaces started to be used for oil palm and rubber plantations. As a result, in 1970, more than 123,000 ha of oil palms, and 131,500 ha of rubber were planted in Malaysia; and throughout this period, the productions of rubber and oil palms became the main contributors for Malaysia's economy, by providing the benefits of foreign exchange income, capital creation, and by generating employment [12].

- The First National Agricultural Policy (1984-1991).

The period between 1984 and 1991, was characterized as an important threshold in the transformation and development of Malaysian economy. During this time, the rapid expansion of the manufacturing sector, altered the relative importance of the agricultural segment, affecting it with big challenges, such as: favorable policies towards the manufacturing section; labor shortage; the increase of production costs; and the land competition with other sectors.

Nonetheless, in 1984, was created as well, the First National Agricultural Policy (NAP1), which encompassed the issues of rural poverty and imbalance income between the commercial, and the traditional farmers. In that way, the principal objectives of this policy, were: (a) to eradicate poverty among traditional small holders; and (b) to increase the value of the agricultural produce for export markets. Throughout this time, Malaysia was abundant with labor, as well as with adequate land that was suitable for agriculture [13].

- The Second National Agricultural Policy (1992-2010).

The Second National Agricultural Policy (NAP2) was the extension of NAP1. This policy was designed to concentrate in the different challenges that the Agricultural sector had been facing; especially the one, of meeting the demand for agro-food products in the domestic and global markets. Similarly, the NAP2 puts a lot of emphasis on suitable productivity, and competitiveness. Likewise, the strategies used to achieve these objectives were: (a) optimize the utilization of resources to diversify the cultivation of export crops; (b) accelerate agro-based industrial development that generates more off-farm opportunities for small holders, to earn additional income; (c) enhance Research and Development (R \& D) to overcome the production processes, labor shortage, and other constraints in the agricultural sector; (d) maximize the participation of the private sector to transform it into a more competitive and efficient one; (e) improve the human resource development through training [14].

- The Third National Agricultural Policy (1998-2010).

This policy (NAP3) was a revised version of the NAP2; it was developed after the government realized the effect of the 1997-1998 Asian Financial Crisis (AFC); as well as the consequences of the liberation of the financial markets to the Malaysia's economy. The AFC was a wakeup call for the government, in order to comprehend the importance of agriculture as the food provider for the people. In that sense, NAP3, was formulated to address the challenges faced by the agricultural sector, such as: the economic structure changes (due to the lack of arable land); shortage labor (due to competition with other sectors); and the efficiency of resources utilization to improve the competitiveness. Moreover, other preoccupations that they had, were related with the availability of food for domestic consumption. In that way, the objectives of NAP3 were: (a) to improve the food security; (b) to increase the productivity and competitiveness of the agricultural sector; (c) to deepen linkages with other sectors; (d) to create new sources of growth within the 
sector; (e) and to conserve and utilize natural resources on a sustainable basis [15].

- The National Agro-Food Policy (2011-2020).

The continuing challenges in the agricultural sector, such as: competition for land with other sectors; labor shortage; and production cost increase, required the implementation of a new set of strategic directions. As an example, the competition for land use between food production and bioenergy, is expected to grow from $8 \%$ in 2008 to $20 \%$ in 2020 . Conjointly, in the global scenario, the world population is expected to grow from 6.2 billion people in 2010 to 9.2 billion people in 2050; not to mention that the climate change will definitely affect the food production commodity; and the trade liberalization, as well as the changes of lifestyle due to higher disposable income, are matters, that with no doubt, require special attention and direction.

Saying that, the National Agro-Food Policy (NAP4) was developed to address challenges in the domestic and global markets to ensure sustainable production for food security and safety. Concurrently, NAP4 has been put in place, to tackle the issues of the sustainable agriculture, and the competitiveness of the agro-food industry with food safety and nutrition aspects along its chain value. The NAP4 aims to reform and transform the agro-food industry in order to become a more modern and dynamic industry. Under this initiative, the agricultural sector is targeted to increase the Gross National Income by RM 28.9 billion to reach RM 49.1 billion by 2020 [16].

\section{Malaysia's Market, Crop Production, Trade and Consumer's Food Service Value}

\subsection{Malaysia’s Market Values for 2013}

Malaysia registered a total GDP of $\$ 316.2$ billion USD.

In that year, Malaysia was the 43rh most populous country in the world with a projected population of 29.7 million people; however, by 2020 is expected to reach the 32.4 million people [17].
Malaysia is considered as one the world's youngest populations in the world, as in 2013, the median age was 27.6 years old; and by 2030 is predicted to grow up to the 34.3 years old.

The annual consumer expenditure per capita was estimated in \$5,605 USD; and from that total, it was calculated that they spent $20.7 \%$ ( $\$ 1,160$ USD) on food and non-alcoholic beverages; slightly lower number than the Asia Pacific average of $22.7 \%$, but higher than Canada's proportion of 9.6\%.

From 2009 to 2012 the foodservice industry showed a stable year-on-year growth over the $5 \%$.

Interestingly enough, as the population has become more concerned with diabetes, hypertension, and obesity, consumers now are choosing healthier and more wellness products. From 2012 to 2014, the sales in the health and wellness category were expected to grow by a compound annual growth rate (CAGR) of $5.9 \%$ reaching a total of $\$ 3.1$ billion USD.

In 2012 the agricultural sector employed $11.1 \%$ of the workforce and was estimated at an 11.4\% GDP [18].

\subsection{Malaysia's Crop Production Value from 2008-2012}

Until 2012, the oil palm industry was the largest agricultural sector and used more than $70 \%$ of the country's arable land [19].

Until that year, the top domestic crops in Malaysia were: oil palm fruit, oil palm, and palm kernels. From 2008 to 2012, the oil palm fruit has been the leading crop in terms of production volume. However, from 2011 to 2012, the oil fruit palm and the oil palm showed a production decrease of $0.7 \%$ (Table 1 ).

In 2012 the banana production performed the best volume growth with $9.7 \%$.

From 2008 to 2012 the fresh vegetable production had a significant augmentation of $17.9 \%$ [20].

\subsection{Malaysia's Trade Value for 2012}

Malaysia is a net exporter of agri-food and seafood 
Table 1 Crop production in Malaysia-Top ten crops (tonnes).

\begin{tabular}{llllll}
\hline Top ten crops & 2008 & 2009 & 2010 & 2011 & 2012 \\
\hline Oil palm fruit & $88,672,000$ & $87,825,000$ & $84,965,000$ & $94,557,600$ & $93,925,150$ \\
Oil palm & $17,734,441$ & $17,564,937$ & $16,993,717$ & $18,911,520$ & $18,785,030$ \\
Palm kernels & $4,577,000$ & $4,504,000$ & $4,292,000$ & $4,706,000$ & $4,850,000$ \\
Rice, paddy & $2,353,000$ & $2,511,043$ & $2,464,830$ & $2,575,988$ & $2,750,404$ \\
Natural rubber & $1,072,400$ & 857,019 & 900,000 & 926,000 & 970,000 \\
Sugar cane & 850,000 & 850,000 & 800,000 & 800,000 & 820,000 \\
Coconuts & 555,120 & 459,640 & 550,140 & 562,556 & 606,530 \\
Fresh vegetables & 290,359 & 396,010 & 547,397 & 550,134 & 560,000 \\
Bananas & 272,331 & 279,762 & 332,639 & 306,283 & 335,974 \\
Pineapples & 384,673 & 357,654 & 331,081 & 309,331 & 334,400 \\
\hline
\end{tabular}

Source: Ref. [20].

Table 2 Malaysia's top agri-food \& seafood imports from the World, 2012.

\begin{tabular}{|c|c|c|c|c|c|}
\hline Commodity & $\begin{array}{l}\text { Import value } \\
\$ \text { million USD }\end{array}$ & $\begin{array}{l}\text { Top suppliers and } \\
\text { market share \#1 }\end{array}$ & $\begin{array}{l}\text { Top suppliers and } \\
\text { market share \#2 }\end{array}$ & $\begin{array}{l}\text { Top suppliers and } \\
\text { market share \#3 }\end{array}$ & $\begin{array}{l}\text { Canada's } \\
\text { share }\end{array}$ \\
\hline $\begin{array}{l}\text { Sugar cane (raw, solid form } \\
\text { without adding flavor/color) }\end{array}$ & $9,754.70$ & Brazil 50.87\% & Thailand 21.45\% & Australia $14.50 \%$ & 0 \\
\hline $\begin{array}{l}\text { Oil palm (refined but not } \\
\text { chemically modified) }\end{array}$ & $9,091.00$ & Indonesia 99.5\% & South Africa $0.39 \%$ & Singapore $0.03 \%$ & 0 \\
\hline $\begin{array}{l}\text { Cocoa beans (whole or } \\
\text { broken-raw or roasted) }\end{array}$ & $8,784.90$ & Ghana 33.25\% & Indonesia $28.05 \%$ & Ivory Coast $13.8 \%$ & 0 \\
\hline $\begin{array}{l}\text { Oil palm (raw not chemically } \\
\text { modified) }\end{array}$ & $7,962.90$ & Indonesia 87.79\% & Thailand 6.29\% & $\begin{array}{l}\text { Papua New Guinea } \\
2.75 \%\end{array}$ & 0 \\
\hline $\begin{array}{l}\text { Soybean (oilcake \& } \\
\text { other-solid residue, } \\
\text { whether/not ground }\end{array}$ & 6,135 & Argentina $93.55 \%$ & China 3.76\% & India .93\% & 0 \\
\hline $\begin{array}{l}\text { Rice (semi or wholly milled, } \\
\text { polished or not) }\end{array}$ & $6,026.50$ & Vietnam $69.68 \%$ & Thailand $12.10 \%$ & Pakistan $11.60 \%$ & 0 \\
\hline Food preparations Nesoi & $5,974.20$ & Singapore $27.32 \%$ & $\begin{array}{l}\text { United States } \\
14.64 \%\end{array}$ & Netherlands 9.82\% & $0.84 \%$ \\
\hline Cotton (not carded or combed) & $5,455.90$ & Brazil 23.95\% & Mali $12.3 \%$ & United States $10.4 \%$ & $0.08 \%$ \\
\hline $\begin{array}{l}\text { Corn (maize), other than seed } \\
\text { corn }\end{array}$ & $5,370.90$ & Argentina $47.87 \%$ & India $22.81 \%$ & Brazil 19.86\% & $0.01 \%$ \\
\hline $\begin{array}{l}\text { Corn (maize) seed, certified, } \\
\text { excluding sweet corn }\end{array}$ & $3,956.50$ & Argentina $41.3 \%$ & Brazil 29.3\% & India $21.5 \%$ & $0.00 \%$ \\
\hline
\end{tabular}

Source: Global Trade Atlas, 2014.

products. In 2012, the agri-food and seafood trade excess was calculated at $\$ 11.7$ billion USD, with imports valued at $\$ 17.5$ billion USD, and exports valued at $\$ 29.2$ billion USD. Furthermore, Malaysia’s agri-food and seafood imports have been growing since 2007, at a CAGR of $14.5 \%$. In addition, Malaysia's top agri-food and seafood imports in 2012 were: sugar cane, oil palm (refined), cocoa beans, oil palm (raw), and oilcake soybeans (Table 2). In addition, the key supporting countries for trading were: Indonesia, China, Thailand, India, and Argentina. Likewise in that same year, Canada was the seventeenth largest supplier of the total agri-food and seafood products to Malaysia, with a $1.11 \%$ share. On the other hand, Canada's agri-food and seafood imports from Malaysia were estimated at \$170.1 million USD; being the oil palm, cocoa, margarine and vegetable oil, the top imports. Nevertheless, Canada registered an agri-food and seafood deficit of \$62.7 million USD with Malaysia [21].

\subsection{Malaysia's Consumer's Food Service Value from 2010 to 2012}

Malaysian consumers keep being cost conscious 

Natural Resources, Policies, Market and Fundings

Table 3 Malaysian consumer foodservice at a glance.

\begin{tabular}{lll}
\hline Consumer foodservice & 2010 & 2012 \\
\hline Sales (\$ million USD) & $8,984.30$ & $9,989.90$ \\
Outlets & 29,442 & 30,721 \\
Transactions ('000) & $1,253,776.50$ & $1,352,698.00$ \\
Average sales/outlet & 305,153 & 325,181 \\
Average sales/transaction & 7.17 & 7.39 \\
\hline
\end{tabular}

Source: Ref. [19].

about their expenses, as a consequence of the living cost increase, and the food price escalation, making them spend less money on dinning out. The fact was demonstrated with the $5.1 \%$ growth of the food service sales value from 2011 to 2012 (Table 3). In conjunction, Malaysian consumers are nowadays looking for healthier menu choices, due to the increasing tendency of diabetes, hypertension and obesity among the population, which has made foodservice operators add healthier food choices to their menus [19]. Interestingly enough, as a result of all these changes and new variables, from 2008 to 2012, the Malaysian foodservice industry grew at a CAGR of $4.6 \%$. The fast food, and the $100 \%$ home delivery were top performing subsectors with a CAGR of $9.2 \%$, and $19.9 \%$ respectively, during 2008 to 2012 [22].

\section{Fundings for Agriculture in Malaysia}

As the Malaysian government understands the importance of increasing the food supply in the country, the 2016 Federal Budget assigned RM 5.3 billion to the Ministry of Agriculture and Agro-based Industry, for economic activities in the agricultural sector. According to the Prime Minister Datuk Seri Najib Abdul Razak, this objective will be accomplished through four main initiatives: namely cultivation; infrastructure upgrade; opening new farmers' markets; and youth agropreneur development programs. In addition, the Prime Minister also mentioned that RM 450 million have been allocated in various high-impact programs, such as: fruit and vegetable cultivation; matching and research grants for herbal products; and fish cage farming.
Furthermore, a total of RM 180 million will be distributed for the upgrading of drainage and irrigation infrastructure in the Integrated Agricultural Development areas throughout the country.

On the other hand, the Federal Agricultural Marketing Authority (FAMA), which is the responsible one of the marketing of agricultural products, received RM 190 million to: implement a price reduction program; to add 50 more farmer's markets; and to establish 150 new 1Malasia People’s Agrobazaars (ABR1M). Likewise, in order to encourage the involvement of the youth in this sector, RM 90 million have been allocated to continue with the Young Agropreneur Development Program [23].

Complementarily, as Malaysia aspires to become a developed country, it nourishes its research culture; being the public sector a significant contributor for the agricultural research funding. In fact, the government ministries that coordinate these research are:

(1) Ministry of Science, Technology and Innovation (MOSTI) - Has been proving funds to research under the following grants:

- Science Fund-Grant provided by the government to carry out $\mathrm{R} \& \mathrm{D}$ projects that can contribute to the discovery of new ideas and the advancement of knowledge in applied sciences, focusing on high impact and innovation research.

\section{- TECHNOFUND (Pre-commercialization} Fund)_This grant scheme aims to stimulate the growth and innovation success of Malaysian enterprises by increasing the level of R \& D and its commercialization. This system provides funding for technology development, up to the pre-commercialization stage, with the commercial potential of creating new businesses and generating economic wealth for the nation.

- INNOFUND (Pre-commercialization Fund)-By realizing the importance of innovation for wealth creation, and social well-being, the Government initiated this grant, which is focused on: Enterprise Innovation, in order to increase the participation of 
micro-businesses and individuals in innovative activities; Community Innovation, which emphases in assisting community groups in translating knowledge and ideas into products, processes or services that might improve the socio-economic standing and quality of the community life.

(2) Ministry of Higher Education (MOHE) - Under the 10th Malaysia Plan and following the tendency of strengthening the research and innovation, the Ministry of Higher Education allocated RM 741 million for research funding, during 2011 and 2012; and was divided into:

- Fundamental Research Grant Scheme (FRGS) - This scheme promotes research involved in early discovery of knowledge that can contribute to the increased level of intellectuality and the creation of new technologies.

- Exploratory Research Grant Scheme (ERGS) - ERGS covers basic areas that can support the country's strategic agenda, such as: Pure and Applied Sciences; Technology and Engineering; Clinical and Health Services; Social Sciences; Arts and Applied Arts; Natural Sciences and National Heritage; and Defense and Security.

- Long Term Research Grant Scheme (LRGS) - Characteristics of this scheme: it is for fundamental research that needs more than 3 years; it must be a multi-institutional and multi-disciplinary research; it must be a problem-based research, inter-discipline, and inter-institutional; it must be program/cluster based; the duration of the research must be between 3-5 years; the ceiling fund is of RM 3 million per project.

- Prototype Research Grant Scheme (PRGS)-This scheme finances the pre-commercialization of prototypes; its duration should be between 1 to 2 years; the ceiling fund is of RM $500 \mathrm{~K}$ per project.

(3) Research University Grant Scheme-The five leading Research Universities have been receiving large amounts of money from the Ministry of Higher
Education since 2007 [24].

\section{The Seed Industry in Malaysia}

In 1970, after recognizing the importance of food crops, and the relevance of increasing the local production, as well as of reducing the food import bill, the Malaysian government launched the "Buku Hijau" (Green Book) Policy; which in addition of pursuing the mentioned concerns, it also promoted the significance and benefits of high quality seeds.

The modernization of the national seed industry in Malaysia started in 1979, with the implementation of the National Seed Project (NSP), after receiving support as a loan, from the World Bank. The implementation of the NSP led to the establishment of seven seed testing laboratories, and seed processing plants. Since then, the Department of Agriculture (DOA), and the Malaysian Agricultural Research and Development Institute (MARDI), have been involved in supplying quality seeds and planting materials to the farmers. Until 2012, there were nine seed processing centers and 10 seed testing laboratories, particularly developed, for paddy seeds. Likewise, since the 1980's, undergraduate Seed Technology courses have been taught at the University Putra Malaysia (UPM), formerly known as Universiti Pertanian Malaysia (Agriculture University of Malaysia); and since 1990s postgraduate courses have been offered as well. Nowadays, UPM is known as a center of excellence for research and learning seed sciences. In 1981, MARDI established the Production and Seed Technology Unit; which, after the restructure of the institution in 2002, became the Planting Material, Seed and Livestock Production Unit with the main objectives of producing quality planting materials developed by MARDI, and by those recommended by the Ministry of Agriculture and Agro-based Industry (MOA); and of maintaining the purity and quality of the seeds.

Moreover, the Third National Agricultural Policy (1998-2010), outlined the importance of an active 
private sector involved in the production of the planting materials, in order to address in a better way, the needs and the adequate supply of quality seeds to the country. As a consequence, in 2008, the National Seed Association of Malaysia (NSAM) was established as an official forum in which producers, exporters, importers, scientists, and extension agents could interact and discuss about topics related to the seed crop industry. By 2011, the National Seed Council (NSC) was established under MOA; and consequently, the Seed Crop Technical Committee was established under the NSC, which was chaired by the Director General of DOA. As a result, on the 28th of September of 2011, the Malaysian Cabinet approved the National Agro-food Policy which was drafted by the Seed Crop Technical Committee. This new National Ago-food Policy replaced the National Agricultural Plan; addressing the issue of food supply in Malaysia.

Notwithstanding, a substantial factor that has contributed in the development of the seed industry in Malaysia, is the fact of having the "Legislation" in place; and a way of doing it was with the creation of the Protection of New Plant Varieties (PNPV) Act that was legislated in 2004; but came into force in October of 2008. Remarkably enough, up to 2012, 94 applications of new plant varieties have been registered, including: 9 industrial crops; 18 cereals; 11 fruits; 28 ornamentals; 3 mushrooms; 1 herb; 19 forestry plants; and 5 vegetables. Additionally, in 2012, twenty five Newly Protected Varieties appeared on a Seed Gazette, including: 3 Chrysanthemum; 2 Dendrobium; 19 Acacia; 1 Papaya.

Likewise, since 1970, the DOA has implemented a Seed Certification Scheme for rice seed production; which contributed to produce more certified rice than what it is required for the country's demand. In 2012 as well, the Seed Certification Scheme for clonal seedlings fruits was launched, in order to obtain uniform, pure and high quality seedling productions.

Nonetheless, as in the past, Malaysia did not emphasize on the seed production other than for rubber, oil palm and rice; nowadays the country relies mostly on imported seeds to sustain the population's demand. Until 2012, Malaysia was importing 90\% of the vegetables, $95 \%$ of the corn, and $100 \%$ of the melon consumed in the country. As a result, Malaysia is now facing certain limitations towards the development of the seed industry, which are:

- Lack of new local varieties-Local seed production is low and is unable to meet local demand because the local inbred varieties are incapable to compete with superior imported hybrid varieties.

- Lack of mandatory seed quality control system-Still, there is no enforcement of a seed quality control system in Malaysia. However, in 2010, DOA established a voluntary seed and planting material certification structure with rice and fruit clones.

- Unorganized information of the seed industry-So far, there are various agencies involved in the seed industry, but their functions are not well coordinated. As a consequence, there is an inefficient manner of sharing information; which has led to an ineffective planning, monitoring and evaluation of the seed industry.

- Inadequate number of trained personnel in the seed industry - In the last twenty years, few varieties have been produced, in part, due to the lack of emphasis on agricultural research funding, contributing to low financial support to train personnel. Besides, graduates have no interest in plant breeding and seed technology, because of the lack of job prospect. Hence, universities are not giving focus on plant breeding and seed technology in their curriculum; only the Universiti Putra Malaysia offers seed technology courses for undergraduate and postgraduate level. In addition, local seed producers are unable to recruit young qualified plant breeders and seed technologies.

- Lack of private sector involvement-Private seed companies are only interested in seed trading rather 
than production of vegetables and corn seeds.

Conjointly, in order to ensure sufficient supply of quality seeds, and to develop successfully the seed in industry in Malaysia, strategic areas have been identified to strengthen the industry, which are:

- Conducive Policy for the Development of the Seed Industry-In 2011, as it was mentioned before, the National Agro-food Policy was approved, focusing on the agro-food sectors development, by ensuring food supply, improving food processing, and by increasing high-value exports. Additionally, this policy aims to augment the food production and the people's income, besides avoiding any food crisis in the country.

- Capacity Building to Strengthen the Seed Industry-The Malaysian government has been focusing on reinforcing the local seed industry by providing incentives for the production of certified seeds, in order to attract private participation to the industry. The government has also been providing funding to improve the capabilities of the existing human resources, through local/international training; short term courses; as well as through graduate and postgraduate studies. The higher learning institutions, such as university, polytechnic and community college are encouraged to include subjects on plant breeding and seed technology.

- Development of the Seed Industrial Zone-A seed Industrial Zone will be developed at the Permanent Crops Food Production (TKPM) Bukit Sapi, Lenggong Perak (80 ha) for the production of breeder, foundation and certified seeds.

- Strengthen the Implementation of Seed Quality Control System-The control of seed quality could be achieved through effective implementation of the Seed Certification Scheme. Likewise, to add more strength to the scheme, the government plans to upgrade eight existing seed testing laboratories; establishing two new seed testing laboratories located in Sabah and Sarawak, and the formation of the National Seed Testing Laboratory in Selangor. These seed laboratories shall be accredited by the International Seed Testing Association (ISTA).

- Establishment of Centralized Integrated Data Management System-Malaysian seed industry database system has to be developed as an online basis, by establishing the Centralized Integrated Data Management System. The functions of this system should involve: databases of seed supply and demand; databases of imported and exported seed; database with the national listing, as well as the recommended list for cultivation; establishment of DNA fingerprinting database for varieties; setting up online gene bank database and monitoring the performance of the seed industry [25].

\section{Conclusions}

It is quite interesting to see the evolution of agriculture and the seed sector in Malaysia. Knowing about the policies, fundings, natural resources, etc., that have been involved in this entire process, definitely gives an adequate picture of the trajectory of the country in terms agriculture, food supply and even the demand. Learning about the indefatigable will of Malaysia, of becoming one day a developing country, capable of producing their own food with high quality standards, it really demonstrates the courage, organization and consciousness that many other countries would need to improve their economies.

\section{References}

[1] FAO (Food and Agriculture Organization of the United Nations). 2016. Country Fact Sheet Malaysia. AQUASTAT (Global Water Information Systems). 6/07/2016.

[2] CIA (Central Intelligence Agency). 2009. The World Factbook: Malaysia. Government Printing Office, 1999.

[3] APSA (The Asia \& Pacific Seed Association). 2006. Country Report: No. 33. The Development of the Seed Industry in Malaysia. Kuala Lumpur, Malaysia. 2006.

[4] FAO (Food and Agriculture Organization of the United Nations). 2009. Back to office report Project: GCP/RAS/241/JPN. Thierry Facon, 3/11/2009.

[5] Mei Toh S. 2013. Brief \#5 of 8: Federation of Malaysia. Agribusiness Large-Scale Land Acquisitions and Human 
Rights in Southeast Asia. Updates from Indonesia, Thailand, Philippines, Malaysia, Cambodia, Timbor-Leste and Burma. Forest Peoples Programme. Edited by Sophie Chao.

[6] Sami, S. 1999. "The Encyclopedia of Malaysia." The Environment. Kuala Lumpur: Archipelago Press, Volume 1, 1998.

[7] FAO (Food and Agriculture Organization of the United Nations). 2012. Water Report - 37. AQUASTAT (Global Water Information Systems). Available at: www.fao.org/nr/water/aquastat/countries_regions/mys/in dex.stm.

[8] Ismail, R., and Jajri, I. 1998. "Human Capital and Economic Growth in Malaysia: A Simulation Model.” Kajian Malaysia 16 (1\&2): 78-88.

[9] Ministry of Finance Malaysia. 2016. Budget. Federal Government Administrative Centre 62592 Putrajaya. Percetakan Nasional Malaysia Berhad.

[10] Ministry of Finance Malaysia. 2013. Malaysia Economic Report 2013/2014. Ministry of Finance. Kuala Lumpur.

[11] Dardak, R. A. 2015. Transformation of Agricultural Sector in Malaysia through Agricultural Policy. Food and Fertilizer Technology Center-Agricultural Policy Platform (FFTC-AP). Food and Fertilizer Technology Center for the Asian and Pacific Region. Malaysian Agricultural Research and Development Institute (MARDI), Malaysia, available at: http:ap.fftc.agnet.org/ap_db.php?id=386.

[12] PEMANDU. 2010. Economic Transformation Report Programme: A Roadmap for Malaysia. Prime Minister Department. Kuala Lumpur.

[13] Ministry of Agriculture Malaysia. 1983a. National Agriculture Policy (1984-1991). Executive Summary. Ministry of Agriculture Malaysia. Kuala Lumpur.

[14] Ministry of Agriculture Malaysia. 1983b. Second
National Agriculture Policy (1992-2010). Executive Summary. Ministry of Agriculture Malaysia. Kuala Lumpur.

[15] Ministry of Agriculture Malaysia. 1999. Third National Agricultural Policy (1998-2010). Executive Summary. Ministry of Agriculture. Kuala Lumpur.

[16] Ministry of Agriculture and Agro-based Industry. 2011. National Agro-food Policy (2011-2020). Ministry of Agriculture and Agro-food Industry. Kuala Lumpur.

[17] Euromonitor International. 2013. World Consumer Lifestyle Databook 2013. Euromonitor International PLC, 2013.

[18] CIA (Central Intelligence Agency). 2014. The World Factbook 2013-2014. Bernan Assoc., 2014.

[19] Euromonitor International. 2014. World Consumer Lifestyle Databook 2914: Key Trends. Euromonitor International PLC, 2014.

[20] FAOSTAT (Food and Agriculture Organization of the United Nations-Statistical Data Base). 2013. Agricultural Production-Malaysia.

[21] Global Trade Atlas. 2013. Import and Export Statistics-Malaysia.

[22] Agriculture and Agri-Food Canada. 2014. Market Overview Malaysia. Market Access Secretariat Global Analysis Report, Canada.

[23] The Sun Daily. 2015. Budget 2016 Allocates RM5.3 Billion for Agricultural Activity. The Sun Media Corporation SdnBhd (221220-K). October 2015. Available at: www.thesundaily.my/news/1591932.

[24] Rahman, Z. A. 2012. "Agricultural Research and Development in Malaysia.” J. ISSAAS. 18 (2): 22-33.

[25] Ginibun, F. C., and Ugab, A. W. 2012. Current Status of the Integrated Seed Sector in Malaysia. Department of Agriculture, Putrajaya, Malaysia. Malaysian Agricultural Research and Development Institute, Serdang, Selangor, Malaysia. 